\title{
TRAINING MEDICAL STUDENTS TO IMPROVE THE MANAGEMENT OF PEOPLE WITH EPILEPSY
}

\author{
Ana L.A. Noronha1,2, MD, PhD; Paula T. Fernandes ${ }^{1,2}, M S c, P h D ;$ \\ Maria da Graça G. Andrade3 ${ }^{3}, M D, P h D ;$ Silvia M. Santiago 3 , MD, PhD; \\ Josemir W. Sander ${ }^{4,5}, M D, P h D, F R C P ; L i M . L i^{1,2}, M D, P h D$
}

\begin{abstract}
Purpose: To evaluate the knowledge, attitude and perception of medical students prior to and after a training course about epilepsy. Methods: We used a KAP questionnaire with sixty-one questions which assesses knowledge, attitude and practice of epilepsy. Questionnaires were completed by 185 medical students, before and after epilepsy training. We compared the answers to see whether the lecture had changed the knowledge, attitude and practice in epilepsy. Results: One hundred and six students completed the questionnaire before an eight hour course on epilepsy and 79 students completed the questionnaire one year after the course. Comparison of the knowledge scores prior to (mean=53.9, standard deviation=11.4) and after the course (mean=63.8, standard deviation=11.9) showed that students had improved knowledge after the course (t-test=5.6, $p<0.001)$. Discussion: Training course on epilepsy for medical students can promote improvement in the knowledge, attitudes and perception re ga rding epilepsy, which is maintained one year later. These results highlight the importance of continuous educational programs within the Medical Curriculum.
\end{abstract}

KEY WORDS: epilepsy, educational courses, training, education.

\begin{abstract}
Capacitação de estudantes de medicina para o atendimento de pacientes com epilepsia
RESUMO - Objetivo: Avaliar conhecimentos, atitudes e percepção sobre epilepsia em estudantes de medicina antes e depois de curso de capacitação. Método: Foi utilizado o questionário KAP da Campanha Global "Epilepsia fora das sombras", liderada pela OMS, ILAE e IBE. Este questionário avalia conhecimento, atitude e percepção sobre epilepsia em 61 questões. Foi aplicado este questionário em 185 estudantes de medicina, antes e depois de cursos de capacitação sobre epilepsia. As questões foram comparadas para analisar as mudanças obtidas com o treinamento. Resultados: Cento e seis estudantes de medicina responderam ao questionário antes do curso de capacitação e 79 estudantes responderam após um ano do curso. A comparação feita a respeito do conhecimento com estes estudantes mostrou que os mesmos melhoram seu conhecimento com os cursos (pré-teste: nota média $=53,9 ; D P=11,4$ vs. pós-teste: nota média $=63,8$; $\mathrm{DP}=11,9 ; \mathrm{t}$-test=5,6; $p<0,001)$. Discussão: 0 curso de capacitação promove melhoras no conhecimento, atitude e percepção sobre epilepsia, mesmo após um ano. Estes resultados salientam a importância de programas de educação continuada dentro do currículo médico.
\end{abstract}

PALAVRAS-CHAVE: epilepsia, cursos de capacitação, treinamento, educação.

Epilepsy is the most common and serious neurological condition all over the world ${ }^{1-4}$. Based on our epidemiological survey ${ }^{5}$ it is estimated that about one million people in Brazil have active epilepsy, of whom approximately $40 \%$ do not receive adequate treatment ${ }^{5}$. Consequently, epilepsy is considered a public health problem, especially in resource-poor countries.

Studies $^{1-3}$ have shown that some health profes- sions lack sufficient knowledge to deal with epilepsy, which may result in a high treatment gap. To imp rove this situation, we suggest that better education of health professionals can be instituted, especially at the undergraduate level of medicine.

This study, part of phase II of the National Demonstration Project on Epilepsy in Brazil, part of the WHO/ILAE/IBE Global Campaign Against Epilepsy, executed by ASPE, Assistência à Saúde de Pacientes

'Departament of Neurology - State University of Campinas (UNICAMP); ${ }^{2}$ Assistência à Saúde de Pacientes com Epilepsia (ASPE), Campinas, Brazil; ${ }^{3}$ Departament of Preventive Medicine - State University of Campinas (UNICAMP); ${ }^{4}$ Epilepsy Institute of the Netherlands, SEIN, Heemstede, Achterweg 5, 2103 SW Heemstede, the Netherlands; ${ }^{5}$ D e partment of Clinical and Experimental Epilepsy, UCL Institute of Neurology, London UK. 
com Epilepsia ${ }^{6}$, aims to evaluate the knowledge, attitude and perceptions of medical students prior to and after an epilepsy training course.

\section{METHOD}

Subjects - Students of the $5^{\text {th }}$ and $6^{\text {th }}$ years of the Medicine Course of UNICAMP, Campinas, Brazil.

Instrument - The KAP Questionnaire (Knowledge, Attitude and Perception) of the Global Campaign "Epilepsy out of the Shadows", from WHO, ILAE and IBE ${ }^{6}$. This questionnaireevaluates knowledge, attitude andperceptions with 61 closed questions.

Procedure-A pre-test of KAP of epilepsy was set for students in the $5^{\text {th }}$ year. After this first evaluation, we delive red a course, of eight hours duration, highlighting information on the management of people of epilepsy; this included the nature of epilepsy, epilepsy diagnosis and tre atment, epilepsy in special situations (women, older people, children), myths and beliefs and psycho-social aspects.

We delivered twelve courses during 2003, as a part of the discipline of Community and Preventive Medicine ("Social Medicine"), with approximately nine students in each course. The post-test $w$ as set at the end of the $6^{\text {th }}$ undergraduate year to evaluate any changes since the intervention (one year later).

Each student received a booklet ent itled "Epilepsy: a t reatable condition", a guideline for AED prescription and a folder containing information on epilepsy treatment and diagnosis. Each question in the knowledge section of the questionnairewas given a score for the correct answer, and the final grade was based on the total score achieved, as a percentage between zero and 100 (see appendix), so that we could compare the performance prior to and after the training. We did not identified the respondents, thus a nonpaired t-test was used to assess significance of the score achieved prior and after the training.

\section{RESULTS}

Prior to training, 106 medical students completed the questionnaire ( $58 \%$ women; mean age $=23$

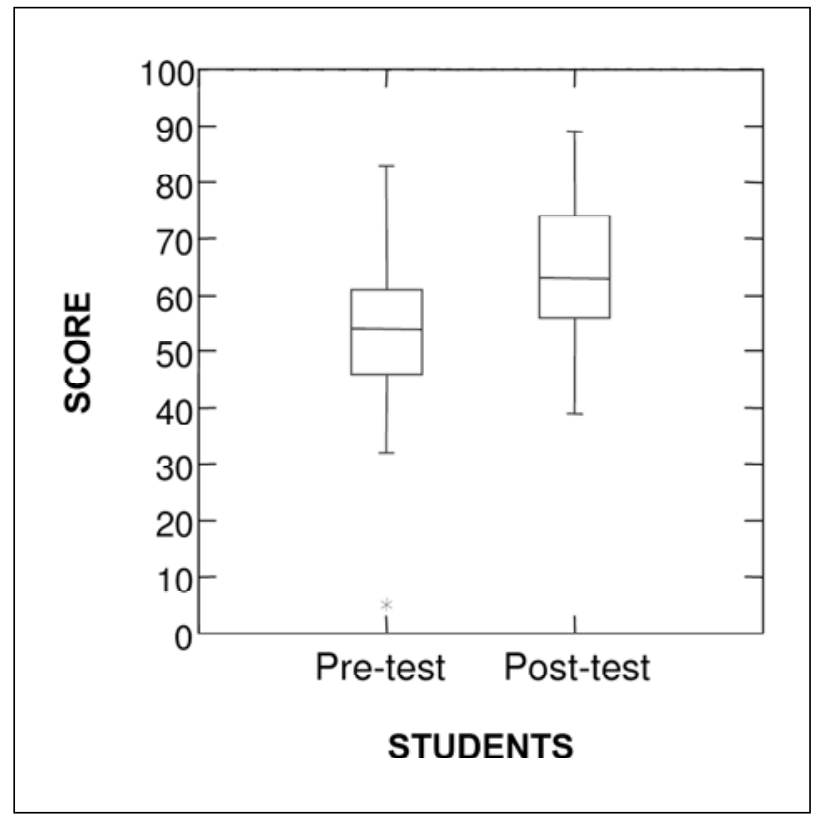

Fig 1. Knowledge test score of students pre and post-training.

years old). Seventy-nine students also completed the post-test questionnaire ( $35 \%$ women; mean age $=24$ years old) one year later.

The results are presented according the three items of the KAP questionnaire: knowledge, attitudes and perception. The comments and observations of the students are presented at the end of the results.

Comparison of knowledge scores prior to (mean= 53.9, standard deviation=11.4) and after the education (mean=63.8, standard deviation=11.9) showed that students had improved knowledge after the training (t-test=5.6, $\mathrm{p}<0.001$ ) (Fig 1).

Comments made by the students - Thirty-five (33\%) students expressed their opinion about the course, stating that it had significantly improved their knowledge about epilepsy. They there fo re felt more

Table 1. Attitudes towards epilepsy.

\begin{tabular}{|c|c|c|c|c|c|c|}
\hline Questions & \multicolumn{3}{|c|}{ Pre-test } & \multicolumn{3}{|c|}{ Post-test } \\
\hline Have you ever seen an epileptic seizure? & \multicolumn{3}{|c|}{65.1} & \multicolumn{3}{|c|}{83.5} \\
\hline Do you have any relatives with epilepsy? & \multicolumn{3}{|c|}{23.6} & \multicolumn{3}{|c|}{21,5} \\
\hline Are you able to recognize an epileptic seizure. & \multicolumn{3}{|c|}{41} & \multicolumn{3}{|c|}{61} \\
\hline Beliefs about epilepsy & Yes & No & DNK & Yes & No & DNK \\
\hline People with epilepsy can exercise. & 51.9 & 23.6 & 24.5 & 69.6 & 22.8 & 7.6 \\
\hline People with epilepsy can drive cars. & 50.0 & 27.4 & 22.6 & 67.1 & 27.8 & 5.1 \\
\hline People with epilepsy can have children. & 97.2 & 0 & 2.8 & 98.7 & 0 & 1.3 \\
\hline People with epilepsy can work in any type of professional activity. & 34.9 & 36.8 & 28.3 & 32.9 & 55.7 & 11.4 \\
\hline
\end{tabular}

Results presented in percentage: DNK, do not know. 


\begin{tabular}{lcccccccccc} 
& \multicolumn{4}{c}{ Pre-test } & \multicolumn{4}{c}{ Post-test } \\
\cline { 2 - 10 } & TA & A & WO & D & TD & TA & A & WO & D & TD \\
\hline There should be more openness about epilepsy. & 65.9 & 30.2 & 3.8 & 0 & 0.9 & 65.8 & 31.6 & 2.5 & 0 & 0 \\
Epilepsy is sign of weakness. & 0 & 0 & 0.9 & 22.7 & 76.4 & 1.3 & 0 & 1.3 & 17.7 & 79.7 \\
People with epilepsy can be treated by primary care centers. & 16.9 & 67.9 & 8.6 & 6.6 & 0 & 39.2 & 50.6 & 6.4 & 3.8 & 0 \\
Epilepsy is a treatable condition. & 32.1 & 60.4 & 4.7 & 2.8 & 0 & 51.9 & 45.6 & 2.5 & 0 & 0 \\
Excess of alcohol by the parents is a cause for epilepsy. & 0 & 0 & 51.8 & 12.3 & 35.9 & 0 & 7.6 & 35.4 & 45.6 & 11.4 \\
People with epilepsy cannot have children. & 0 & 1.9 & 14.1 & 58.5 & 25.5 & 2.5 & 0 & 11.5 & 39.2 & 46.8 \\
People with epilepsy can have leadership positions. & 47.2 & 42.4 & 7.6 & 0 & 2.8 & 60.8 & 30.4 & 6.3 & 2.5 & 0 \\
Excessive suffering during childhood may lead to epilepsy. & 0 & 0.9 & 70.7 & 33.9 & 35.9 & 0 & 0 & 12.7 & 39.2 & 48.1 \\
People with epilepsy can lead normal lives. & 45.3 & 50.0 & 3.8 & 0.9 & 0 & 55.9 & 39.2 & 4.9 & 0 & 0 \\
People with epilepsy can contribute to the community. & 69.8 & 26.4 & 2.9 & 0 & 0.9 & 69.6 & 27.9 & 2.5 & 0 & 0 \\
People with epilepsy can be better treated in institutions. & 4.7 & 0.9 & 31.2 & 30.2 & 33.0 & 0 & 6.3 & 12.7 & 39.2 & 41.8 \\
I feel comfortable and confident to manage epilepsy. & 0.9 & 13.2 & 22.7 & 45.3 & 17.9 & 2.5 & 39.2 & 24.1 & 29.1 & 5.1 \\
People with epilepsy are responsible for their condition. & 3.8 & 0.9 & 13.3 & 33.0 & 49.0 & 2.5 & 11.4 & 14 & 32.9 & 39.2 \\
People with epilepsy can get married. & 71.7 & 25.5 & 1.9 & 0 & 0.9 & 73.4 & 24.0 & 2.5 & 0 & 0 \\
People with epilepsy are more irritable. & 0.9 & 0 & 10.5 & 29.2 & 59.4 & 1.3 & 3.8 & 6.3 & 35.4 & 53.2 \\
\hline
\end{tabular}

Results presented in percentage: TA, totally agree; $A$, agree; WO, without opinion; TD, totally disagree; $D$, disagree.

confident about dealing with epilepsy, especially in the primary care system. The students expressed a desire for more details and more clinical cases and suggested that the course could be repeated in the $6^{\text {th }}$ undergraduate year.

\section{DISCUSSION}

This study describes the course on epilepsy for un de rgraduate students in a public university in Brazil. We observed that this course can promote better knowledge of epilepsy, as showed by the difference of the score in pre-test and post-test.

In this study, we showed how the reformulation of the undergraduate medical course can contribute to improving the management of epilepsy and to decreasing the related stigma. The students felt more c o $\mathrm{m}$ fo rtable dealing with epilepsy after completing the course. It may be relevant that the course was taught in the discipline of Community and Preventive Medicine rather than in Neurology. This may have led students to incorporate the concept that the management of epilepsy is not the exclusive domain of the specialist.

In conclusion, this study evaluated the knowledge, attitudes and perception regarding epilepsy, and allowed a comparison of these aspects before and after a specific course on epilepsy. In the pre-test, the results showed that some students already had good information about epilepsy, perhaps because of the regular neurology course, taught in the $4^{\text {th }}$ year. However, we observed a lack of knowledge, especially rega rding clinical treatment, epilepsy in women and perceptions. After the course, an improvement was obse red in knowledge of epilepsy which was maintained after a year. These results highlight the importance of continuous educational programs to improve the knowledge, attitudes and perception regarding epilepsy within the medical curriculum.

Acknowledgments - We wish thank to Carlos Tucassa, coordinator assistant of unde rgraduate course of Faculty of Medical Sciences - Unicamp for helping applying and collecting the questionnaires. This study was supported by FAEP (Fundação de Apoio ao Ensino e à Pesquisa)/UNICAMP.

\section{REFERENCES}

1. Reynolds EH. The ILAE/IBE/ WHO Global Campaign against epilepsy: bringing epilepsy "Out of the shadows:. Epilepsy Behav 2000;1:S3-S8.

2. Sander JW. The epidemiology of epilepsy revisited. Curr Opin Neurol 2003;16:165-170.

3. Saraceno B. The WHO World Health Report 2001 on mental health. Epidemiol Psichiatr Soc 2002;11:83-87.

4. Shorvon SD, Farmer PJ. Epilepsy in developing countries: a review of epidemiological, sociocultural, and treatment aspects. Epilepsia 1988; 29(Suppl 1):S36-S54.

5. Noronha ALA, Borges A, Marques LH, et al. Prevalence and pattern of epilepsy treatment in diffe rent social-economic classes in Brazil. Epilepsia, ${ }^{* *}\left({ }^{*}\right): 1-6,2007$, doi:10.1111/j.1528-1167.2006.00974.

6. Li LM, Sander JW. National demonstration project on epilepsy in Brazil. Arq Neuropsiquiatr 2003;61:153-156. 
Appendix. Knowledge test score.

\begin{tabular}{|c|c|c|c|}
\hline Questions & & Correct answer & Score \\
\hline $8 a$ & Do you know patients' rights or limitations related to epilepsy? & Yes & 1 \\
\hline $8 b$ & Describe the limitations & $\begin{array}{l}\text { Driving is not allowed if seizures are } \\
\text { not controlled, work at heights, radical } \\
\text { sports, work with machineries... }\end{array}$ & 2 \\
\hline $9 a$ & Can patients with epilepsy do any type of exercise? & No & 1 \\
\hline $9 b$ & May patients with epilepsy drive? & No & 1 \\
\hline $9 c$ & Can patients with epilepsy have children? & Yes & 1 \\
\hline $9 d$ & Can patients with epilepsy work in any type of professions? & No & 1 \\
\hline $9 e$ & Explain why you answer NO for questions $9 a$ to $9 d$ & & 2 \\
\hline $12 a$ & Can somnolence be an AED side-effect? & Yes & 1 \\
\hline $12 b$ & Can anxiety be an AED side-effect? & Yes & 1 \\
\hline $12 c$ & Can dizziness be an AED side-effect? & Yes & 1 \\
\hline $12 d$ & Can vomiting be an AED side-effect? & Yes & 1 \\
\hline $12 e$ & Can headache be an AED side-effect? & Yes & 1 \\
\hline $12 f$ & Can ataxia be an AED side-effect? & Yes & 1 \\
\hline $12 \mathrm{~g}$ & Can impotence be an AED side-effect? & Yes & 1 \\
\hline $12 \mathrm{~h}$ & Can increased seizure frequency be an AED side-effect? & Yes & 1 \\
\hline $12 i$ & Can hirsutism be an AED side-effect? & Yes & 1 \\
\hline $12 \mathrm{j}$ & $12 \mathrm{a}$ to $12 \mathrm{i}$ are correct & Yes & 2 \\
\hline $13 a$ & Can women with epilepsy have normal deliveries? & Yes & 1 \\
\hline $13 b$ & Can women with epilepsy breastfeed? & Yes & 1 \\
\hline $13 c$ & Can women with epilepsy use oral contraceptives? & Yes & 1 \\
\hline $13 d$ & Can women with epilepsy have tubal ligation? & Yes & 1 \\
\hline $14 a$ & Should AEDs be interrupted during pregnancy? & No & 1 \\
\hline $14 b$ & Explain: & $\begin{array}{l}\text { The risk benefit between having } \\
\text { seizures and fetal malformation weighs } \\
\text { more in favor of using the drugs to } \\
\text { avoid seizures }\end{array}$ & 2 \\
\hline $15 a$ & A re AEDs associated with a high percentage of fetal malformation? & No & 1 \\
\hline $15 b$ & Explain & $\begin{array}{l}\text { The risk of fetal malformation for } \\
\text { women taking AEDs is below } 10 \%\end{array}$ & 2 \\
\hline 16 & What is the percentage of controlled epilepsy? & $80 \%$ & 2 \\
\hline 17 & Are convulsions the only type of epilepsy presentation? & No & 1 \\
\hline 18 & Is convulsion synonymous with epilepsy? & No & 1 \\
\hline 20 & What is the age range for febrile convulsion? & 0 to 5 years & 1 \\
\hline 21 & Should febrile convulsions always be treated with AEDs? & No & 2 \\
\hline $22 a$ & Is photosensitivity one of trigger factors associated with epilepsy? & Yes & 1 \\
\hline $22 b$ & Can sudden interruption of AEDs trigger seizures? & Yes & 1 \\
\hline $22 c$ & Can sleep deprivation trigger seizures? & Yes & 1 \\
\hline $22 d$ & Can severe stress trigger seizures? & Yes & 1 \\
\hline $22 e$ & $22 \mathrm{a}$ to $22 \mathrm{~d}$ are correct & Yes & 2 \\
\hline $23 a$ & Is head trauma a risk factor for epilepsy? & Yes & 1 \\
\hline $23 b$ & Are meningitis and encephalitis risk factors for epilepsy? & Yes & 1 \\
\hline $23 c$ & Is tuberculosis a risk factor for epilepsy? & Yes & 1 \\
\hline $23 d$ & Are obstetric complications risk factors for epilepsy? & Yes & 1 \\
\hline $23 e$ & Are gastric ulcers a risk factor for epilepsy? & No & 1 \\
\hline $23 f$ & Is flu a risk factor for epilepsy? & No & 1 \\
\hline
\end{tabular}


Appendix. Knowledge test score (continuation).

\begin{tabular}{|c|c|c|c|}
\hline Questions & & Correct answer & Score \\
\hline $23 g$ & Is high fever a risk factor for epilepsy? & No & 1 \\
\hline $23 \mathrm{~h}$ & Is malaria a risk factor for epilepsy? & Yes & 1 \\
\hline 24 & Can epilepsy start at any age? & Yes & 1 \\
\hline 25 & What type of AED would you use in a status epilepticus? & Options: Diazepam, Phenytoin & 2 \\
\hline 26 & What would you do during a convulsion? & & \\
\hline $26 a$ & Turn patient on his/her side? & Yes & 1 \\
\hline $26 \mathrm{~b}$ & Remove anything that could be a danger to the patient? & Yes & 1 \\
\hline $26 c$ & Pull the patient's tongue? & No & 1 \\
\hline $26 d$ & Put something in the patient's mouth to avoid tongue biting? & No & 1 \\
\hline $26 e$ & Give oxygen? & Yes & 1 \\
\hline 27 & When starting AEDs the physician should; (Choose the correct answer) & $\begin{array}{l}\text { Start with the minimal dosage in } \\
\text { monotherapy }\end{array}$ & 1 \\
\hline 28 & Which AED is often used in generalized epilepsy? & Option: Valproic acid & 2 \\
\hline 29 & Which AEDs are often used in partial seizures? & Option: Phenobarbital, Carbamazepine & 2 \\
\hline $30 a$ & Is electroencephalography part of epilepsy investigation? & Yes & 1 \\
\hline $30 \mathrm{~b}$ & Is electrocardiography part of epilepsy investigation? & No & 0 \\
\hline $30 c$ & Is skull xray part of epilepsy investigation? & No & 0 \\
\hline $30 d$ & Is brain CT part of epilepsy investigation? & Yes & 1 \\
\hline $30 \mathrm{e}$ & Is brain MRI part of epilepsy investigation? & Yes & 1 \\
\hline $30 f$ & Is brain mapping part of epilepsy investigation? & No & 0 \\
\hline $30 \mathrm{~g}$ & Is CSF tap part of epilepsy investigation? & No & 0 \\
\hline $30 \mathrm{~h}$ & Is psychiatric investigation part of epilepsy investigation? & No & 0 \\
\hline 31 & EEG should be requested: & $\begin{array}{l}\text { To help in the diagnosis of } \\
\text { types of epilepsy. }\end{array}$ & 2 \\
\hline 32 & Neuroimaging should be requested: & Whenever a brain lesion is suspected & 2 \\
\hline 33 & In patients on AEDs: & & \\
\hline $33 a$ & $\begin{array}{l}\text { Women should not get pregnant, as there is a high risk for } \\
\text { the offspring }\end{array}$ & False & 1 \\
\hline $33 b$ & Any form of contraceptive can be effective & False & 1 \\
\hline $33 c$ & The risk of fetal malformation is around $50 \%$ & False & 1 \\
\hline $33 d$ & AEDs should always be reduced during pregnancy & False & 1 \\
\hline $33 e$ & $\begin{array}{l}\text { Women should not breast feed, because of high levels of AED in } \\
\text { the maternal milk. }\end{array}$ & False & 1 \\
\hline
\end{tabular}

The scores of each question were added, and the final sum was converted to a percentage ranging from zero to 100. 